an A-G mutation at nucleotide 3243 of the mitochondrial tRNA $^{\text {Leu(UUR) }}$. J Clin Endocrinol Metab 80: 1290-1294

8. Kotsimbos N, Jean-Francois MJB, Huizing M et al. (1994) Rapid and noninvasive screening of patients with mitochondrial myopathy. Human Mutation 4: 132-135

9. Zeviani M, Amati P, Bresolin N et al. (1991) Rapid detection of the A-G (8344) mutation of mtDNA in Italian fam- ilies with myoclonic epilepsy and ragged red fibres (MERRF). Am J Hum Genet 48: 203-211

10. Maassen JA, Kadowaki T (1996) Maternally inherited diabetes and deafness: a new diabetes subtype. Diabetologia 39: $375-382$

\section{Amylin innocent in essential hypertension?}

\section{Dear Sir,}

It is increasingly apparent that the data linking the metabolic defects of insulin resistance with hypertension are associative rather than causal and that the precise nature of this relation has still not been explained. Long-term infusions of insulin both systemically [1] and intrarenally [2] have failed to increase blood pressure and patients with insulinomas were shown not to be hypertensive [3,4]. It thus appears that hyperinsulinaemia in itself is unlikely to be directly responsible for increases in blood pressure.

After our identification that amylin (co-secreted with insulin from pancreatic beta cells) activated the renin-angiotensin system [5], we and others proposed that excess amylin action, likely to be present in hyperinsulinaemic patients, could be implicated in the pathogenesis of obesity-related hypertension. This hypothesis was supported by reports that patients with insulinoma did not over-secrete amylin [6] and were not characteristically hypertensive $[3,4]$. In contrast, a patient with a tumour secreting an amylin-like substance had unexplained hypertension and subsequently died from cerebral haemorrhage [7].

We here report several lines of evidence that argue against the implication of excess amylin action in the pathogenesis of hypertension. Firstly, although the amylin antagonist AC625 blocked the effects of exogenous human amylin to stimulate renin secretion in humans, it had no effect, when infused for 4 days, on blood pressure in hyperamylinaemic subjects. Secondly, dogs made hyperinsulinaemic, hyperamylinaemic, hyper-reninaemic and hypertensive by fat-feeding, showed no effect after 1 week of continuous infusion of the potent amylin antagonist, AC253. Finally, in a 1-year study of 507 patients with Type II (non-insulin-dependent) diabetes mellitus (body mass $90.6 \pm 18.2 \mathrm{~kg}$; means \pm SD), all of whom were treated with insulin and some three times daily with injections of the human amylin analogue, pramlintide, at doses (30, 75, $150 \mu \mathrm{g}$ three times daily), plasma amylin activity was seen equal to or greater than that in hypertensive subjects (up to $50 \mathrm{pmol} / \mathrm{l}$ ). There was no dose-related change in either systolic or diastolic blood pressures (Fig. 1).

The absence of effect of amylin, amylin agonists and amylin antagonists on blood pressure is surprising because of the action of other renin-angiotensin system-modulating agents (for example, renin inhibitors, angiotensin-converting enzyme inhibitors and angiotensin II receptor antagonists) on arterial pressure. It is possible that a theoretical propensity for amylin to promote sodium retention and hypertension through its activation of the renin-angiotensin system is countered by recently identified diuretic and natriuretic effects of amylin [8].

Yours sincerely,

A. Young, O. Kolterman, J. Hall

Corresponding author: A. A. Young, Amylin, 9373 Towne Centre Drive, San Diego, CA 92121, USA

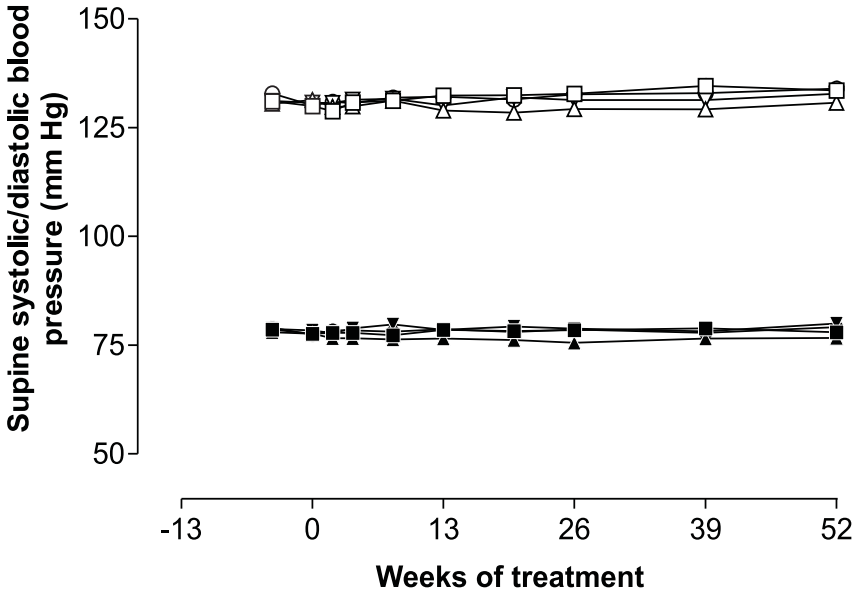

Fig. 1. Systolic pressures $\square$ Placebo $n=132 ; \triangle 30 \mu \mathrm{g} n=116$; $\nabla 75 \mu \mathrm{g} n=133$; $\bigcirc 150 \mu \mathrm{g} n=126$. Diastolic pressures: $\square$ Placebo; $\boldsymbol{\Delta} 30 \mu \mathrm{g} ; \boldsymbol{\nabla} 75 \mu \mathrm{g} ; 150 \mu \mathrm{g}$

\section{References}

1. Brands MW, Mizelle HL, Gaillard CA, Hildebrandt DA, Hall JE (1991) The hemodynamic response to chronic hyperinsulinemia in conscious dogs. Am J Hypertens 4: 164-168

2. Hall JE, Brands MW, Mizelle HL, Gaillard CA, Hildebrandt DA (1991) Chronic intrarenal hyperinsulinemia does not cause hypertension. Amer J Physiol 260: F663-F669

3. Sawicki PT, Heinemann L, Starke A, Berger M (1992) Hyperinsulinaemia is not linked with blood pressure elevation in patients with insulinoma. Diabetologia 35: 649-652

4. Pontiroli AE, Alberetto M, Pozza G (1992) Patients with insulinoma show insulin resistance in the absence of arterial hypertension. Diabetologia 35: 294-295

5. Young AA, Rink TJ, Vine W, Gedulin B (1994) Amylin and syndrome-X. Drug Develop Res 32: 90-99

6. Nieuwenhuis MG, VanMansfeld AD, VanUnnik JA, Berends MJ, Lips CJ (1992) No constant relationship between islet amyloid polypeptide (IAPP) and insulin expression in insulinomas. Neth J Med 41: 264-271

7. Stridsberg M, Wilander E, Öberg K, Lundqvist G, Eriksson B (1992) Islet amyloid polypeptide-producing pancreatic islet cell tumor. Scand J Gastroenterol 27: 381-387

8. Vine W, Smith P, LaChappell R, Blase E, Young A (1998) Effects of rat amylin on renal function in the rat. Horm Metab Res 30: 518-522 